\begin{tabular}{|l|l|l||}
\hline \multicolumn{2}{|c|}{ PublisherInfo } \\
\hline \hline PublisherName & $:$ & BioMed Central \\
\hline \hline PublisherLocation & $:$ & London \\
\hline \hline PublisherImprintName & $:$ & BioMed Central \\
\hline \hline
\end{tabular}

\title{
Maurice Wilkins dies
}

\begin{tabular}{|l|l|l||}
\hline \multicolumn{2}{|c|}{ ArticleInfo } \\
\hline \hline ArticleID & $:$ & 5006 \\
\hline \hline ArticleDOI & $:$ & $10.1186 /$ gb-spotlight-20041007-01 \\
\hline \hline ArticleCitationID & $:$ & spotlight-20041007-01 \\
\hline \hline ArticleSequenceNumber & $:$ & 69 \\
\hline \hline ArticleCategory & $:$ & Research news \\
\hline ArticleFirstPage & $:$ & 1 \\
\hline \hline ArticleLastPage & $:$ & 3 \\
\hline \hline & & RegistrationDate : 2004-10-7 \\
\hline ArticleHistory & $:$ & OnlineDate \\
\hline \hline ArticleCopyright & $:$ & BioMed Central Ltd2004-7 \\
\hline \hline ArticleGrants & $:$ & \\
\hline \hline ArticleContext & $:$ & 130595511 \\
\hline \hline
\end{tabular}




\section{Stephen Pincock}

Email: stephen@thescientisteurope.com

\section{Alison McCook}

Email: abmccook@yahoo.com

Maurice Hugh Frederick Wilkins, joint winner of the Nobel Prize in 1962 for his role in the discovery of the double helix structure of DNA, died on Tuesday (October 5), Kings College London announced on Wednesday. King's, where Wilkins was still a member of staff, said the eminent researcher died in the hospital surrounded by his family.

Wilkins was born in 1916 and studied physics at St. John's College, Cambridge. During the Second World War, he worked on the separation of uranium isotopes, and then continued this work in Berkeley, Calif., where he joined the Manhattan Project.

As James Watson wrote in his 1968 book, The Double Helix, Wilkins was profoundly disillusioned when the bombs were dropped on Japan. "He considered forsaking science altogether to become a painter in Paris, but biology intervened," Watson wrote. When the war ended, Wilkins became lecturer in physics at St. Andrews University, and then moved to the Medical Research Council Biophysics Unit at King's College London.

Wilkins became assistant director of the Medical Research Council Unit in 1950 and deputy director in 1955. In crucial studies, his group obtained x-ray diffraction images of the structure of DNA that were of unprecedented clarity. It was for this work, and the years his group spent verifying the hypothetical model which Watson and Crick constructed, that he was awarded the Nobel.

Ray Gosling, professor emeritus at the University of London, met Wilkins in 1949 when he joined the Biophysics Unit, headed by Sir J.T. Randall. He recalled that he and Wilkins shared the equivalent of a "eureka moment" after studying a mass of DNA.

The researchers found that if they added water to the asbestos-like substance, it turned into a gel, out of which they could pull fibers. Gosling wound 35 DNA fibers around a paperclip and, late one evening, brought the specimen to the chemistry department and took an x-ray. "Up came all these wonderful spots," he recalled, demonstrating that the DNA had crystallized.

Wilkins "went around for days telling anyone that would listen that he had realized genes could crystallize," Gosling said. The year after, Wilkins described in a lecture the crystallization of DNA. A young James Watson was sitting in the audience, and the rest was history.

Gosling noted that when Watson and Crick built the model of the double helix, they offered a coauthorship to Wilkins, who declined, because he had not helped build the actual model. However, the title of Wilkins' autobiography, The Third Man of the Double Helix, says it all, Gosling told us. "Wilkins has ended up being very much the third man."

Indeed, Michael Levitt of Stanford University, who met Wilkins in the 1960s when he was a biophysics student at King's College, said he believed that the work of Watson and Crick might not have 
been possible without Wilkins' critical contributions. "It was the major discovery of the 20th century, and Wilkins was part of it," Levitt told us.

Gosling said that, outside of his work on DNA, Wilkins, like other researchers, had initially been very excited about the atomic bomb, but later "pulled back" when he realized its horrible consequences.

Consequently, Wilkins subsequently became very involved in trying to make science more responsible, Gosling said. He was president of the British Society for Social Responsibility in Science, and in the 1970s he established an undergraduate course on the social impact of the biosciences. "He was one of the few Nobel Laureates who was leading people's thoughts that way," Gosling said.

\section{References}

1. Nobel Prize in Physiology or Medicine 1962, [http://nobelprize.org/medicine/laureates/1962/ index.html]

2. Maurice Wilkins: Obituary, King's College London news release, October 6, 2004., [http://www.kcl.ac.uk/phpnews/wmview.php?ArtID=688]

3. Ray Gosling, [http://www.kcl.ac.uk/dna/speakers/gosling.html]

This PDF file was created after publication. 